\title{
EVALUATION OF THE LEARNING PROCESS OF ISLAMIC EDUCATION IN THE IMPLEMENTATION OF CURRICULUM 2013 IN MALUKU TENGAH
}

\author{
St. Jumaeda \\ Program Studi PAI FITK IAIN Ambon \\ jumaeda@iainambon.ac.id
}

\begin{abstract}
Abstact: This research was conducted to obtain information about the learning process of Islamic education at the high school in Maluku Tengah. In this study applied a method of evaluation studies Program, collection of data obtained through the study of documents, interviews, questionnaires and observation. The data is then classified into the category of excellent, good, sufficient, less, and very less, based on standards that have been set. The findings in the evaluation of the learning program at Islamic Education for high school in Maluku Tengah district, shows that the quality of the learning process, including both categories. The learning process is determined by the element or the following aspects; (1) the Teacher's performance is judged by category, with the acquisition of average score 4.14 or $82.79 \%$ of the maximum score, (2) Learning Facilities are assessed either by obtaining the average score of 3.71 or $74.17 \%$ of the maximum score, (3) Climate class is rated good with the acquisition of the mean score of 3.61 or $72.04 \%$ of the maximum score. (4) the attitude of the learners are assessed either by obtaining the average score 4.01 or $80.09 \%$ of the maximum score. (5) the learning motivation of learners assessed either by obtaining the average score or $77.713 .88 \%$ of the maximum score. So based on the results of the assesment and the categorisation then determined that the quality of the learning process the Islamic education judged included on the category either, with the acquisition of the average score or $3.8877 .50 \%$ of the maximum score.
\end{abstract}

Keywords: Islamic Education Learning, Curriculum 2013

Abstrak: Penelitian ini dilakukan untuk memperoleh informasi tentang proses pembelajaran Pendidikan Agama Islam pada SMA di Maluku Tengah. Dalam penelitian ini diterapkan metode studi evaluasi Program, pengumpulan data diperoleh melalui studi dokumen, wawancara, kuesioner dan observasi. Data kemudian diklasifikasikan ke dalam kategori sangat Baik, Baik, Cukup, kurang, dan sangat kurang, berdasarkan standar yang telah ditetapkan. Temuan dalam evaluasi program pembelajaran PAI pada SMA di Kabupaten Maluku Tengah, menunjukkan bahwa kualitas dari proses pembelajaran, termasuk kategori baik. Proses pembelajaran ditentukan oleh unsur atau aspek berikut; (1) Kinerja Guru yang dinilai dengan kategori baik, dengan perolehan rerata skor 4,14 atau $82,79 \%$ dari skor maksimum, (2) Fasilitas Pembelajaran yang dinilai baik dengan perolehan rerata skor 3,71 atau $74,17 \%$ dari skor maksimum, (3) Iklim Kelas yang dinilai baik dengan perolehan rerata skor 3,61 atau $72,04 \%$ dari skor maksimum. (4) Sikap peserta didik yang dinilai baik dengan perolehan rerata skor 4,01 atau 80,09\% dari skor maksimum. (5) Motivasi Belajar Peserta didik yang dinilai baik dengan perolehan rerata skor 3,88 atau $77,71 \%$ dari skor maksimum. Sehingga berdasarkan hasil penialian dan kategorisasi maka ditentukan bahwa kualitas proses pembelajaran PAI dinilai termasuk pada kategori baik, dengan perolehan rerata skor 3,88 atau $77,50 \%$ dari skor maksimum.

Kata kunci: Pembelajaran PAI, Kurikulum 2013

\section{PENDAHULUAN}

Semenjak tahun 1945, kurikulum pendidikan nasional telah mengalami beberapa kali pergantian dan perubahan, yaitu tahun 1947, 1952, 1964, 1968, 1975, 1984, 1994, 1999, 2004, 2006, dan 2013. Perubahan tersebut merupakan konsekuensi logis dari terjadinya perubahan sistem politik, sosial budaya, ekonomi dan iptek 
dalam masyarakat berbangsa dan bernegara. Sebab kurikulum sebagai seperangkat rencana pendidikan perlu dikembangkan secara dinamis sesuai dengan tuntutan dan perubahan yang terjadi di masyarakat. Semua kurikulum yang pernah ada dirancang berdasarkan landasan yang sama, yakni Pancasila dan UUD 1945, perbedaannya pada penekanan tujuan pendidikan serta pendekatan dalam mewujudkannya.(Jumaeda \& Nur Khozin, 2018 : 2)

Pergantian dan perubahan kurikulum yang telah terjadi di negeri ini ternyata tidak membuat pendidikan mengalami perbaikan. Perubahan kurikulum cenderung berfungsi sebagai alat bongkar pasang untuk melanggengkan kekuasaan. Supriyoko bahkan menyatakan bahwa pergantian kurikulum di Indonesia selama ini tidak selalu didasarkan pada tuntutan perkembangan ilmu pengetahuan dan teknologi, ataupun tuntutan budaya masyarakat setempat, akan tetapi ternyata ada yang lebih didasarkan pada pertimbangan politik. Dalam hal ini adalah pergantian kurikulum pendidikan dari kurikulum 1964 yang dianggap sebagai produk Orde Lama dengan segala kekurangannya menjadi kurikulum 1968 sebagai produk Orde Baru dengan segala kelebihannya saat itu. (Lili Hidayati, 2014)

Pada tahun 2013, bangsa Indonesia dihebohkan dengan pemberlakuan kurikulum baru. Kurikulum itu disebut dengan kurikulum 2013. Walaupun pemerintah telah melakukan uji publik terhadap perubahan kurikulum selama kurang lebih dua tahun, namun masih saja banyak menemui kendala bahkan penolakan dari berbagai pihak. Sebagai sesuatu yang baru, tentunya masih memerlukan persiapan dan sosialisasi lebih jauh agar pihak guru sebagai garda terdepan pendidikan dapat memamahami dan mengimlementasikannya dengan baik. Berbagai upaya dilakukan oleh pemerintah untuk mensosialisasikan kurikulum kurikulum 2013, di antaranya diklat, pelatihan, workshop, TOT tentang implementasi kurikulum 2013.

Pemberlakukan kurikulum 2013 merupakan pengembangan kurikulum sebelumnya yang berbasis kompetensi dan telah dirintis sejak tahun 2004 dan KTSP 2006 yang mencakup kompetensi sikap, pengetahuan, dan keterampilan secara terpadu.(Jumaeda,55:2018) Penyempurnaan pola pikir merupakan salah satu alasan pemberlakuan kurikulum 2013, karena tuntutan masa depan hanya akan terwujud jika ada perubahan dan pergeseran pola pikir. Salah satu yang menjadi harapan perubahan dan pergeseran dari sistem pendidikan adalah proses pembelajaran. Dalam standar proses disebutkan bahwa jika dalam kurikulum sebelumnya, proses lebih terfokus pada domain kognitif, sementara dalam 
kurikulum 2013 ini dilengkapi dengan domain afektif dan psikomotor yang terpadu secara apik. Selain itu, arah pembelajaran juga berubah dari siswa diberi tahu menjadi siswa mencari tahu dari berbagai sumber belajar yang ada. Paling penting untuk diperhatikan adalah di dalam kurikulum 2013 diarahkan agar proses pembelajaran bukan menjadikan guru sebagai satu-satunya sumber belajar, tetapi siswa dituntut untuk aktif kreatif mencari sumber belajar yang lain di luar guru dan sekolahnya.(Jumaeda \& Nurkhozin, 2018: 4)

Tata kelola pada kurikulum 2013, dimulai dengan menetapkan Standar Kompetensi Lulusan, tujuan Pendidikan Nasional, dan kebutuhan. Setelah semuanya ditetapkan baru kemudian dapat ditentukan kurikulumnya yang terdiri dari kerangkan dasar kurikulum dan struktur kurikulum. Berbeda dengan kurikulum sebelumnya, Satuan Pendidikan dan guru tidak diberi kewenangan menyusun silabus karena sudah disusun di tingkat Nasional. Hal ini menjadi nilai plus tersendiri bagi kurikulum 2013 karena guru tidak harus terbebani dengan segala tugas yang terkait dengan penyusunan silabus yang tentunya akan menguras banyak waktu dan tenaga sehingga guru mempunyai kesempatan yang luas untuk mengembangkan proses pembelajaran.

Tujuan pendidikan yang dimaksud di dalam kurikulum 2013 adalah memberikan ilmu pengetahuan secara utuh kepada siswa dan tidak terpecah-pecah. Kurikulum ini menekankan pada keaktifan siswa untuk menemukan konsep pelajaran dengan guru berperan sebagai fasilitator. Implementasi kurikulum 2013 diorientasikan untuk mencetak generasi yang siap di dalam menghadapi masa depan, dengan tujuan untuk mendorong peserta didik mampu lebih baik dalam melakukan observasi, bertanya, bernalar, dan mengkomunikasikan (mempresentasikan) apa yang mereka peroleh atau mereka ketahui setelah menerima materi pembelajaran. (Jumaeda \& Nur Khozin 2018: 4)

Berdasarkan data Dinas Pendidikan Provinsi Maluku bahwa jumlah SMA yang ada di Provinsi Maluku sebanyak 287 sekolah, dari 11 kabupaten/kota yang terdiri atas 194 sekolah negeri dan 93 sekolah swasta, yang tersebar di Kabupaten Buru 13 sekolah, Buru Selatan 15 sekolah, Kepulauan Aru 13 sekolah, Maluku Barat Daya 21 sekolah, Maluku Tengah 75 sekolah, Maluku Tenggara 19 sekolah, Maluku Tenggara Barat 25 sekolah, Seram Bagian Barat 38 sekolah, Seram Bagian Timur 21 sekolah, kota Ambon 36 sekolah dan kota Tual 11 sekolah. (data Dinas Pendidikan Provinsi Maluku Tahun 2018). 
Restrukturisasi dalam pengelolaan lembaga pendidikan pada tingkat sekolah Menengah Atas di provinsi Maluku khususnya di Kabupaten Maluku Tengah ditekankan pada hal-hal peningkatan kualitas proses dengan diwujudkan melalui penyusunan visi misi dan tujuan yang dimuat dalam kurikulum 2013 yang kemudian akan digunakan sebagai acuan atau pedoman dalam penyelenggaraan program pembelajaran, dengan menekankan pada usaha untuk mewujudakan peserta didik yang berahlak mulia, mewujudkan peserta didik yang unggul dalam penguasaan iptek dan pengamalan imtaq, dan mewujudkan peserta didik yang diterima dan dibutuhkan di berbagai lapisan masyarakat. Sejalan dengan maksud tersebut maka peningkatan kualitas proses pembelajaran dengan menggunakan kurikulum 2013 sebagai pedoman atau acuan telah dimplementasikan pada pelaksanaan program pembelajaran pada Sekolah Menengah Atas di Kabupaten Maluku Tengah, termasuk pada pelaksanaan program pembelajaran Pendidikan Agama Islam.

Peningkatan kualitas pembelajaran Pendidikan Agama Islam di Kabupaten Maluku Tengah akan sangat ditentukan oleh hal-hal seperti kesiapan sekolah dalam hal ketersediaan fasilitas penunjang kegiatan pembelajaran, dan profesionalisme guru terutama yang berkaitan dengan kemampuan pemahaman guru dalam melaksanakan program pembelajaran, serta iklim akademik menyangkut situasi yang muncul akibat hubungan antara guru dan siswa atau hubungan antar-siswa, termasuk derajat afeksi positif atau negatif siswa terhadap pembelajaran, dan motivasi belajar siswa atau dorongan dalam diri siswa untuk belajar dan menyelesaikan tugas-tugas, memecahkan masalah maupun mempelajari kompetensi tertentu dalam mata pelajaran dengan sebaik-baiknya berdasarkan standar keunggulan. (Jumaeda \& Nur Khozin 2018: 4)

Peningkatkan kualitas pembelajaran pada program pembelajaran Pendidikan Agama Islam yang diselenggarakan pada Sekolah menengah di Kabupaten Maluku Tengah dapat dilihat dari tiga komponen penting program pembelajaran yang saling terkait, yaitu perencanaan pembelajaran, pelaksanaan proses pembelajaran, dan penilaian. Perencanaan pembelajaran merupakan persiapan mengelola pembelajaran yang akan dilaksanakan pada setiap pertemuan tatap muka. Pelaksanaan proses pembelajaran merupakan kegiatan guru dalam mengelola pembelajaran di kelas. Kegiatan penilaian dilakukan untuk mengukur dan menilai pencapaian kompetensi serta untuk mengetahui kelebihan dan kekurangan dari proses pembelajaran yang telah dilaksanakan. Program pembelajaran dirancang 
secara terencana agar pelaksanaan pembelajaran berjalan dengan baik. Karena saling terkait inilah, maka perencanaan pembelajaran yang baik sangat penting untuk menjamin terlaksananya proses pembelajaran yang efektif dan benar. Penyusunan Standar Proses pendidikan merupakan penentu kegiatan pembelajaran yang dilakukan oleh guru dalam rangka mencapai standar kompetensi lulusan. Karena itu standar proses dapat dijadikan sebagai acuan guru dalam mengelola pembelajaran serta menentukan komponen-komponen yang dapat memberi pengaruh terhadap proses pendidikan. (Jumaeda dan Nursaid,1:2017)

Kecenderungan yang terjadi pada sekolah di Kabupaten Maluku Tengah adalah terdapat guru mata pelajaran yang mengadopsi secara utuh perencanaan pembelajaran yang belum tentu sesuai dengan karakteristik peserta didiknya ini merupakan indikasi bahwa kinerja dan kemampuan atau kompetensi guru tersebut dalam merancang perencanaan pembelajaran masih perlu ditingkatkan sehingga kulitas pembelajaran akan lebih efektif yang pada akhirnya dapat menghasilkan output yang lebih maksimal.

Untuk melihat tingkat pencapaian mutu dan tujuan pendidikan, diperlukan suatu bentuk evaluasi. Menurut Sukardi, tujuan dilakukannya evaluasi adalah sesuai dengan apa yang telah dimuat dalam Undang-Undang Republik Indonesia Nomor 20 Tahun 2003 tentang Sistem Pendidikan Nasional Pasal 57 ayat (1), bahwa evaluasi dilakukan dalam rangka pengendalian mutu pendidikan secara nasional sebagai bentuk akuntabilitas penyelenggara pendidikan kepada pihak-pihak yang berkepentingan, diantaranya terhadap peserta didik, lembaga, dan program pendidikan. (Sukardi, 2009: 1)

Program pembelajaran, merupakan proses yang terpenting karena dari sinilah terjadi interaksi langsung antara pendidik dan peserta didik. Di sini pula campur tangan langsung antara pendidik dan peserta didik berlangsung sehingga dapat dipastikan bahwa hasil pendidikan sangat tergantung dari perilaku pendidik dan perilaku peserta didik. Dengan demikian dapat diyakini bahwa perubahan hanya akan terjadi jika terjadi perubahan perilaku pendidik dan peserta didik. Posisi pendidik dan peserta didik memiliki posisi strategis dalam meningkatkan kualitas pembelajaran.

Proses pembelajaran merupakan serangkaian aktivitas yang terdiri dari persiapan, pelaksanaan, dan evaluasi pembelajaran. Ketiga hal tersebut merupakan rangkaian utuh yang tidak dapat dipisah-pisahkan. Persiapan belajar mengajar 
merupakan penyiapan yang meliputi antara lain Kompetensi Inti dan kompetensi dasar, alat evaluasi, bahan ajar, metode pembelajaran, media/alat peraga pendidikan, fasilitas, waktu, tempat, dana, harapan-harapan, dan perangkat informasi yang diperlukan untuk mendukung pelaksanaan proses belajar mengajar. Kesiapan siswa, baik fisik maupun mental, juga merupakan hal penting. Jadi esensi persiapan proses belajar mengajar adalah kesiapan segala hal yang diperlukan untuk berlangsungnya proses belajar mengajar.

Pelaksanaan proses belajar mengajar, merupakan kejadian atau peristiwa interaksi antara pendidik dan peserta didik yang diharapkan menghasilkan perubahan pada peserta didik, dari belum mampu menjadi mampu, dari belum terdidik menjadi terdidik, dari belum kompeten menjadi kompeten. Inti dari proses belajar mengajar adalah efektivitasnya. Tingkat efektivitas pembelajaran sangat dipengaruhi oleh perilaku pendidik dan perilaku peserta didik. Perilaku pendidik yang efektif, antara lain mengajarnya jelas, menggunakan variasi metode pembelajaran, menggunakan variasi media/alat peraga pendidikan, antusiasme, memberdayakan peserta didik, menggunakan konteks sebagai sarana pembelajaran, menggunakan jenis pertanyaan yang membangkitkan, dan lain sebagainya. Sedang perilaku peserta didik, antara lain motivasi atau semangat belajar, keseriusan, perhatian, karajinan, kedisiplinan, keingintahuan, pencatatan, pertanyaan, senang melakukan latihan soal, dan sikap belajar yang positif.

Peningkatan kualitas pembelajaran Pendidikan Agama Islam sangat ditentukan oleh tiga unsur, yaitu: guru, siswa, dan kurikulum. Ketiga unsur tersebut dapat diasumsikan bahwa (1) Guru, sesuai dengan fungsinya bertugas mengoptimalkan kemampuan siswa dalam belajar atau sering diistilahkan dengan mengajar. Dalam mengoptimalkan kemampuan siswa profesionalisme, kemampuan dan pemahaman guru yang memadai dalam mengajar sangat menentukan peningkatan kualitas pembelajaran sekaligus keberhasilan program pembelajaran mencapai tujuan sebagaimana telah direncanakan di dalam silabus yang telah disusun sebelumnya, (2) Siswa, dengan segala karakteristiknya dalam proses pembelajaran diharapkan secara maksimal dapat mencapai tujuan belajar, dan (3) Kurikulum, adalah merupakan pedoman atau media serta sekaligus merupakan salah satu fasilitas penunjang untuk mencapai tujuan yang diinginkan. Oleh karena itu, maka perlu dilakukan evaluasi pada unsur-unsur tersebut untuk mengidentifikasi 
kualitas proses dan kualitas output pembelajaran khususnya pada pelaksanaan program pembelajaran Pendidikan Agama Islam. (Jumaeda \& Nur Khozin 2018: 10)

\section{METODE}

Evaluasi proses pembelajaran pendididikan agama islam dalam implementasi kurikulum 2013 pada SMA di Maluku Tengah menggunakan metode evaluasi program dengan teknik pengumpulan data berupa observasi, wawancara, angket dan dokumentasi ditabulasi kemudian mengalami peruduksian. Selanjutnya dideskripsikan dalam bentuk kategori. Sumber data yang didapatkan pada setiap unit analisis juga dikonfirmasi dengan metode tri-angulasi yang melibatkan kepala sekolah, wakil kepala sekolah bidang kurikulum dan guru mata pelajaran PAI. Trianggulasi digunakan agar data yang diperoleh akan lebih konsisten, tuntas dan pasti. (Sugiono, 2009: 241)

Penelitian ini mencakup berbagai variabel dan indikator yang terkait dengan komponen-komponen program pembelajaran yang dievaluasi. Masing-masing variabel dari komponen-komponen evaluasi tersebut mempunyai bentuk dan sifat serta sumber data yang berbeda sehingga memerlukan penggunaan metode yang berbeda pula dalam hal pengumpulan data dan analisnya. (Creswell, 2014:22) Penelitian ini dilakukan di SMA yang ada di Kabupaten Maluku Tengah dengan jumlah sekolah sebanyak 10 yang telah menerapkan Kurikulum 2013, berlokasi di Laihitu 3 Sekolah, Salahutu 3 sekolah, dan Masohi 4 sekolah.

HASIL

Penilaian pada evaluasi kualitas proses dilakukan untuk mengidentifikasi proses program pembelajaran Pendidikan Agama Islam, mencakup penilaian terhadap kinerja guru dalam kelas, fasilitas pembelajaran, iklim kelas, sikap peserta didik serta motivasi belajar peserta didik untuk mewujudkan tujuan program pembelajaran khususnya pada pembelajaran Pendidikan Agama Islam yang diselenggarakan pada SMA di Kabupaten Maluku Tengah.

\section{a. Evaluasi terhadap Kinerja Guru}

Evaluasi terhadap komponen kinerja guru dilaksanakan melalui evaluasi pada perencanaan, pelaksanaan dan evaluasi pembelajaran meliputi aspek-aspek, yaitu: Penguasaan materi, Pemahaman karakteristik peserta didik, penguasaan pengelolaan pembelajaran, penguasaan strategi pembelajaran, dan kemampuan melaksanakan penilaian. 
Berdasarkan hasil penilaian peserta didik pada SMA di Kabupaten Maluku Tengah yang dijaring melalui angket yang telah disebarakan, diperoleh gambaran kualitas proses program secara keseluruhan, hasil penilaian dari evaluasi, berdasarkan penilaian peserta didik pada SMA di Kabupaten Maluku Tengah selaku responden terhadap 27 butir pernyataan menghasilkan rerata 4,14 atau $82,79 \%$ kinerja guru pada kategori sangat baik. Hal ini mengindikasikan bahwa secara umum kompetensi yang dimiliki guru ditinjau dari aspek kinerja guru dalam menyelenggarakan program pembelajaran Pendidikan Agama Islam di SMA di Kabupaten Maluku Tengah dinilai sangat baik.

\section{b. Evaluasi Terhadap Fasilitas Pembelajaran}

Gambaran mengenai dukungan fasilitas dalam program pembelajaran Pendidikan Agama Islam pada SMA di Kabupaten Maluku Tengah berdasarkan penilaian dari peserta didik terhadap aspek fasilitas pembelajaran yang dijaring melalui angket, diperoleh hasil bahwa pada butir kondisi ruang pembelajaran menurut hasil penilaian responden terhadap 3 butir pernyataan menghasilkan 79,44\% kondisi baik. Hal tersebut mengindikasikan bahwa kondisi ruang pelaksanaan program pembelajaran Pendidikan Agama Islam dinilai baik.

Pada butir kelengkapan media pembelajaran untuk jawaban responden terhadap 3 butir 68,75\% berada pada kategori baik, hal demikian menunjukkan bahwa kelengkapan media pembelajaran dalam pelaksanaan program pembelajaran Pendidikan Agama Islam pada SMA di Kabupaten Maluku Tengah menurut responden dinilai baik.

Pada butir kondisi media pembelajaran menurut jawaban responden terhadap 3 butir pernyataan menghasilkan $63,61 \%$ berada pada kategori cukup, hal tersebut menandakan bahwa kondisi media pembelajaran yang digunakan dalam pelaksanaan program pembelajaran Pendidikan Agama Islam pada SMA di Kabupaten Maluku Tengah menurut responden dinilai cukup.

Pada butir kelengkapan sumber pembelajaran dari jawaban responden pada 3 butir pernyataan menghasilkan $84,86 \%$ baik. Hal itu menunjukkan bahwa kelengkapan sumber pembelajaran yang terdapat pada SMA di Kabupaten Maluku Tengah dinilai baik dalam mendukung pelaksanaan program pembelajaran Pendidikan Agama Islam.

secara umum dari hasil evaluasi mengenai dukungan fasilitas dalam melaksanakan program Pembelajaran Pendidikan Agama Islam berdasarkan 
penilaian peserta didik pada 12 butir pernyataan menghasilkan rerata 3,71 atau $74,17 \%$ pada kategori baik. Hal tersebut menandakan bahwa fasilitas pembelajaran yang tersedia pada SMA di Kabupaten Maluku Tengah dinilai baik dalam mendukung pelaksanaan kegiatan program pembelajaran.

\section{c. Evaluasi Terhadap Iklim Kelas}

Hasil evaluasi pada aspek iklim kelas berdasarkan penilaian peserta didik memberikan gambaran mengenai kondisi dan suasana iklim kelas dalam program pembelajaran Pendidikan Agama Islam pada SMA di Kabupaten Maluku Tengah menunjukkan bahwa pada butir kekompakan peserta didik berdasarkan penilaian peserta didik terhadap 4 butir pernyataan memperoleh $57.92 \%$ kategori cukup. Hal tersebut mengindikasikan bahwa kondisi dan keadaan peserta didik dinilai cukup.

Pada butir keterlibatan peserta didik berdasarkan penilaian peserta didik terhadap 5 butir pernyataan menghasilkan $74.58 \%$ kategori baik. Hal tersebut mencerminkan bahwa keterlibatan peserta didik dalam pembelajaran dinilai baik.

Pada butir dukungan guru dalam pembelajaran menurut penilaian peserta didik pada 5 butir pernyataan menghasilkan 90,17\% dinilai sangat baik. Hal tersebut membuktikan bahwa dukungan guru dalam pembelajaran Pendidikan Agama Islam pada SMA di Kabupaten Maluku Tengah dinilai sangat baik dan sangat mendukung peserta didik.

Dengan demikian, berdasarkan hasil evaluasi tentang suasana atau kondisi iklim kelas menurut penilaian peserta didik secara keseluruhan terhadap 19 butir pernyataan untuk semua butir, dari hasil tersebut diperoleh rata-rata 3,61 atau $72,04 \%$ dinilai baik. Hal tersebut menunjukkan bahwa kondisi yang menjadi ciri khusus dari kelas mata pelajaran dinilai baik dalam mempengaruhi proses pembelajaran Pendidikan Agama Islam pada SMA di Kabupaten Maluku Tengah.

\section{d. Evaluasi Terhadap Sikap Peserta didik}

Gambaran mengenai sikap peserta didik terhadap kecenderungan dalam mengikuti pelaksanaan program pembelajaran Pendidikan Agama Islam pada SMA di Kabupaten Maluku Tengah menurut hasil penilaian peserta didik menunjukkan bahwa pada butir aspek pemahaman manfaat (Kognisi) berdasarkan penilaian peserta didik terhadap 3 butir pernyataan menghasilkan $81,39 \%$ kategori baik. Hal tersebut mengindikasikan bahwa pemahaman materi yang dimiliki peserta didik khususnya mata Pelajaran Pendidikan Agama Islam pada SMA di Kabupaten Maluku Tengah dinilai baik. 
Pada butir rasa senang terhadap mata pelajaran menurut penilaian peserta didik terhadap 3 butir pernyataan menghasilkan 83,61\% kategori baik. Hal demikian menunjukkan bahwa perasaan peserta didik terhadap pelaksanaan program pembelajaran Pendidikan Agama Islam pada SMA di Kabupaten Maluku Tengah dinilai baik.

Pada butir aspek kecenderungan bertindak berdasarkan penilaian peserta didik terhadap 3 butir pernyataan menghasilkan 75,28\% kategori baik. Hal demikian menunjukkan bahwa kecenderungan peserta didik terhadap mata pelajaran, materi maupun guru dinilai baik.

Secara keseluruhan berdasarkan hasil evaluasi tentang sikap peserta didik dari jawaban terhadap 9 butir pernyataan menurut penilaian peserta didik menghasilkan rata-rata 4,01 atau $80,09 \%$ kategori baik. Hal tersebut berarti sikap peserta didik terhadap materi pelajaran maupun guru dalam menyelenggarakan program pembelajaran Pendidikan Agama Islam pada SMA di Kabupaten Maluku Tengah dinilai baik.

\section{e. Evaluasi Terhadap Motivasi Belajar Peserta didik}

Motivasi belajar peserta didik dalam mengikuti pelaksanaan program pembelajaran Pendidikan Agama Islam pada SMA di Kabupaten Maluku Tengah, dapat diketahui melalui hasil evaluasi yang dijaring melalui angket yang diberikan pada responden peserta didik untuk dinilai. Selanjutnya, jawaban peserta didik terhadap pernyataan mengenai orientasi keberhasilan, antisipasi kegagalan, inovasi dan tanggung jawab yang seluruhnya berjumlah 15 butir pernyataan.

Aspek Orientasi keberhasilan berdasarkan penilaian 48 orang peserta didik terhadap 3 butir pertanyaan menghasilkan 79,31\% kategori baik. Hal tersebut menunjukkan bahwa orientasi peserta didik pada keberhasilan dinilai baik.

Pada butir antisipasi kegagalan, berdasarkan penilaian responden terhadap 3 butir pernyataan menghasilkan $80,00 \%$ kategori baik. Hal demikian menunjukkan bahwa antisipasi peserta didik terhadap kegagalan dalam pelaksanaan program pembelajaran Pendidikan Agama Islam pada SMA di Kabupaten Maluku Tengah dinilai termasuk pada kategori baik. Selanjutnya untuk inovasi peserta didik terhadap program pembelajaran Pendidikan Agama Islam menurut penilaian peserta didik pada 4 butir pernyataan menghasilkan 80,63\% kategori baik. Demikian pula pernyataan mengenai tanggung jawab, dari hasil penilaian responden terhadap 5 butir pernyataan menghasilkan $70,91 \%$ kategori baik. 
Secara keseluruhan berdasarkan penilaian responden terhadap 15 butir pernyataan mengenai motivasi belajar peserta didik, menghasilkan rata-rata untuk semua butir pernyataan, dari hasil tersebut diperoleh rata-rata 3,88 atau $77,71 \%$ kategori baik. Hal tersebut menunjukkan bahwa dorongan untuk berprestasi peserta didik dinilai baik.

Berdasarkan hasil penelitian evaluasi kualitas proses pelaksanaan pembelajaran Pendidikan Agama Islam pada SMA di Kabupaten Maluku Tengah, setelah melalui penilaian yang dilakukan oleh 48 orang peserta didik menunjukan bahwa kualitas proses pembelajaran Pendidikan Agama Islam yang diselenggarakan di SMA di Kabupaten Maluku Tengah dinilai dengan klasifikasi baik dengan perolehan rerata skor 3,88 atau $77,50 \%$ dari skor maksimum.

\section{PEMBAHASAN}

Untuk mengetahui tingkat efektifitas komponen kualitas proses pembelajaran tersebut, dapat dilakukan melalui evaluasi penilaian terhadap: (a) kinerja guru, (b) fasilitas pembelajaran, (c) iklim kelas, (d) sikap peserta didik, dan (e) motivasi belajar.

\section{a. Kinerja guru}

Dalam pelaksanaan program pembelajaran Pendidikan Agama Islam pada SMA di Kabupaten Maluku Tengah, berdasarkan hasil evaluasi bahwa kemampuan guru dalam menunjukkan keterampilan atau kompetensi yang dimiliki pada waktu mengajar di kelas dinilai dengan kategori baik. Hal tersebut ditentukan oleh aspekaspek diantaranya penguasaan materi, pemahaman karakteristik peserta didik, penguasaan pengelolaan pembelajaran, penguasaan strategi pembelajaran dan kemampuan melaksanakan penilaian. Terkait dengan penguasaan materi dalam pelaksanaan pembelajaran guru memiliki kemampuan untuk mengaitkan materi dengan permasalahan yang relevan.

Selanjutnya, mengenai pemahaman karakteristik peserta didik nampak pada dukungan guru terhadap peserta didik yang memiliki pemahaman yang kurang dengan melalui pembelajaran individual dan untuk menghindari hal tersebut, maka dalam perencanaan program pembelajaran atau RPP disesuaikan dengan kondisi, kemampuan dan karakteristik peserta didik, hal tersebut sejalan dengan kriteria Kurikulum 2013 sebagai acuan dalam pelaksanaan program pembelajaran. 
Pada aspek penguasaan pengelolaan pembelajaran, terutama pedoman dalam penyusunan materi pembelajaran, adalah kurikulum yang telah dibuat bersama, kemudian dikembangkan sendiri oleh guru mata pelajaran dengan menggunakan sumber-sumber yang relevan sesuai dengan kemampuan dan kompetensi yang dimiliki guru dengan latar belakang kualifikasi pendidikan sarjana S1. Mengenai perencanaan pembelajaran Pendidikan Agama Islam telah sesuai dengan visi dan misi sekolah serta tujuan pembelajaran, karena telah menggunakan acuan kurikulum 2013 yang disusun dengan memperhatikan kondisi dan karakteristik sekolah. Khusus dukungan fasilitas, sarana dan parasarana yang diperlukan cukup memadai, seperti tersedianya perpustakaan, laboratorium, dan lapangan olah raga yang dapat digunakan untuk mendukung pelaksanaan kegiatan program pembelajaran. Kegiatan program pembelajaran berlangsung dalam suatu proses yang sistimatis menurut model dan pendekatan yang digunakan dalam RPP, yang dimulai dari kegiatan awal, inti dan penutup. Langkah-langkah pembelajaran tersebut adalah seperti yang telah digariskan dalam rancangan RPP sebagai pedoman dalam pembelajaran. Dalam kegiatan pembelajaran guru kadang-kadang menggunakan media pembelajaran, hanya sesuai dengan relevansi materi yang dibawakan dalam kegiatan pembelajaran, dan melakukan pembelajaran tidak sesuai dengan RPP.

Pada aspek penguasaan pengelolaan pembelajaran terkait dengan pemilihan dan pengorganisasian bahan pembelajaran serta penentuan bahan pengayaan dilakukan dengan tetap disesuaikan menurut kemampuan dan karakteristik peserta didik, sedangkan materi dengan waktu dan ruang lingkup urutan yang digunakan dalam pembelajaran cukup sesuai. Kemudian antara sumber dan media pembelajaran dengan kompetensi dasar dan materi pembelajaran sangat sesuai, demikian pula halnya antara sumber dan media pembelajaran sesuai dengan kemampuan peserta didik. Mengenai metode pembelajaran sangat sesuai dengan kompetensi dasar dan sesuai pula dengan materi standar dan alokasi waktu.

Penguasaan pengelolaan pembelajaran juga dibuktikan melalui pelaksanaan proses pembelajaran yang dimulai dari perencanaan, pelaksanaan dan penilaian seluruhnya telah menggunakan kurikulum 2013 sebagai acuan atau pedomannya. Dalam melaksanaan pembelajaran guru cukup mampu dalam menentukan strategi pembelajaran yang akan digunakan untuk memenuhi apa yang dituntut dalam kurikulum 2013, termasuk mampu mengimplementasikan teknik dan strategi 
pengelolaan kelas, sehingga sekolah secara umum cukup kondusif dalam melaksanakan kegiatan pembelajaran.

Selanjutnya, pada aspek penguasaan strategi pembelajaran, strategi untuk meningkatkan sikap kedisiplinan peserta didik dalam mengikuti pembelajaran, maka dikembangkan menejemen dalam pengololaan sekolah dengan selalu menekankan pada disiplin dalam segala aktifitas pelaksanaan kegiatan pembelajaran yang dimuat dalam tata tertib sekolah. Hal tersebut diperjelas dengan adanya ketentuan bahwa apabila ada guru yang berhalangan hadir maka jamnya diisi oleh wali kelas atau guru piket, sehingga tidak ada kesempatan bagi peserta didik untuk tidak mengikuti kegiatan pembelajaran. Dalam kegiatan pembelajaran guru dapat membangun hubungan yang akrab dengan peserta didik, melalui pemberian ruang yang cukup pada peserta didik untuk mengembangkan kreasi dan ide-idenya, selanjutnya guru selalu memberikan dukungan jika ada kegiatan yang akan dilaksanakan oleh peserta didik, sepanjang kegiatan tersebut berkaitan dengan kegiatan pembelajaran, dan hubungan yang baik antara guru dan peserta didik tersebut tidak terbatas pada pembelajaran di kelas saja akan tetapi peserta didik tetap menghormati guru meskipun di luar pembelajaran, bahkan ketika bertemu di luar jam sekolah.

Menyangkut aspek penguasaan strategi pembelajaran, khususnya terkait dengan strategi untuk meningkatkan partisipasi dan keterlibatan peserta didik dalam pembelajaran di dalam kelas dapat dilakukan dengan selalu memberikan kesempatan yang sama kepada peserta didik tanpa ada perbedaan antara satu sama lainnya untuk mengeluarkan pendapat, sedangkan di luar kegiatan pembelajaran dapat dilakukan dengan cara sering menyapa atau mengajak peserta didik untuk berdiskusi mengenai seputar pembelajaran. untuk menjelaskan materi pembelajaran, selain sumber yang disiapkan sekolah, guru juga menggunakan berbagai sumber lain yang relevan dengan materi pembelajaran, yang disajikan dengan selalu menggunakan setrategi secara bervariasi dan pada pelaksanaannya berusaha untuk selalu tepat waktu dalam memulai dan mengakhiri pembelajaran.

Pada aspek kemampuan melaksanakan penilaian, dapat diuraikan bahwa penilaian terhadap peserta didik dilakukan dengan obyektif dan adil, jadi nilai yang diberikan adalah benar-benar sesuai dengan kemampun yang dimiliki peserta didik, dengan tidak membeda-bedakan antara satu sama lainnya meskipun memiliki perbedaan Suku Agama Ras Golongan (SARG), karena masing-masing siswa mempunyai kemampuan yang bervariasi, sehingga guru dapat mengetahui 
perkembangan kemampuan peserta didik pada proses pembelajaran. (Jumaeda, 2016:56) Dengan demikian penilaian adalah benar-benar dapat mengukur kompetensi peserta didik terhadap mata pelajaran yang telah diajarkan. Selanjutnya, guru sering memberikan tugas-tugas untuk dikerjakan dan diselesaikan oleh peserta didik, minimal setiap selesai satu kompetensi dasar diberikan tugas untuk dikerjakan dan diselesaikan oleh peserta didik. Melalui tugas tersebut guru kemudian memberikan balikan (feedback) terhadap tugas-tugas yang dikerjakan peserta didik, dengan membahas secara bersama-sama dengan peserta didik misalnya dengan menanyakan kembali kepada peserta didik apa jawaban dari soal-soal yang telah diselesaikan. Hal tersebut dilakukan dengan menunjuk salah seorang peserta didik secara bergiliran untuk menjawabnya, selanjutnya dilakukan penilaian terhadap hasil belajar dengan melalui penilaian proses yang selalu dilakukan pada saat pembelajaran sedang berlangsung, sedangkan penilaian formatif pada pertengahan semester dan penilaian sumatif pada akhir semester.

Kemampuan guru dalam melaksanakan penilaian, juga dapat ditunjukkan melalui penilaian terhadap tugas-tugas peserta didik, guru memberikan feedback untuk memastikan penguasaan yang dimiliki peserta didik terhadap materi yang diajarkan sebelumnya dan apabila ada materi yang belum tuntas dikuasai peserta didik guru juga memberikan tugas tambahan setelah terlebih dahulu melakukan remedial dan pengayaan. Secara umum dalam melihat ketercapaian tujuan pendidikan pada SMA di Kabupaten Maluku Tengah adalah melalui tercapainya visi dan tujuan sekolah secara keseluruhan, sehingga diharapkan SMA di Kabupaten Maluku Tengah dapat memenuhi apa yang diharapkan yaitu menjadi salah satu sekolah yang sangat dibutuhkan keberadaaannya ditengah-tengah masyarakat.

Secara keseluruhan evaluasi pada komponen kualitas proses pembelajaran menunjukkan hasil yang baik namun terdapat kelemahan utama pada beberapa aspek dari komponen kualitas proses pembelajaran, diantaranya; kinerja guru, melalui jawaban responden terhadap angket yang diberikan diketahui bahwa ternyata aspek yang perlu ditingkatkan, adalah: kurangnya penguasaan strategi pembelajaran yang dimiliki guru mata pelajaran. Berdasarkan hasil evaluasi, data yang diperoleh menurut penilaian responden belum mampu menggambarkan hasil yang lebih maksimal. Karena itu, perlu dilakukan penggunaan gaya mengajar yang lebih variatif, dengan cara demikian deskripsi penguasaan strategi pembelajaran akan menjadi lebih inovatif dan interaktif. 


\section{b. Fasilitas pembelajaran}

Dalam mendukung program pembelajaran Pendidikan Agama Islam pada SMA di Kabupaten Maluku Tengah, dibutuhkan dukungan manajemen yang baik, fasilitas, sarana dan prasarana yang diperlukan dalam menunjang pembelajaran secara umum memadai sehingga menunjang kegiatan PBM, seperti lab. IPA, lapangan olah raga, perpustakaan, dan lain-lain. Tentang kendala yang dihadapi dalam menyelenggarakan manajeman pengelolaan pendidikan adalah dalam hal menyatukan komitmen dalam merumuskan misi sekolah dalam aspek yang lebih proporsional dimana membutuhkan waktu yang tidak singkat sekitar dua atau tiga hari yang diwarnai musyawarah yang cukup alot di dalamnya. Sedangkan jenis Kurikulum yang digunakan sebagai pedoman/ acuan dalam pembelajaran adalah berdasarkan acuan SNP yang diwujudkan dalam kurikulum 2006 dan kurikulum 2013 dan pada tahun 2019 semua sekolah wajib menggunakan kurikulum 2013 pada SMA di Maluku tengah. Kurikulum dan silabus untuk keperluan pelaksaan pembelajaran sudah dirancang dan sekaligus dilampirkan serta dipegang masingmasing untuk semua guru. Secara khusus telah ditentukan bahwa masing-masing untuk semua guru diwajibkan memiliki rancangan RPP.

Mengenai sistem pengelolaan di sekolah ini diantaranya dikembangkan sistim yang mendukung keterlaksanaan administrasi yang dapat meningkatkan pembelajaran yang representatif, tentang perekrutan ketenagaan dan kualifikasi pendidikan guru dapat dilakukan secara formal dan non-formal, secara non-formal terutama kebanyakan dalam hal perekrutan tenaga administrasi, atau atas dasar pertimbangan untuk percepatan proses belajar mengajar, administrasi kantor, perpustakaan, laboran, clening servis dan satpam.

Adapun ciri khusus kurikulum yang dikembangkan pada SMA di Maluku Tengah ini adalah berorientasi pada ilmu pengetahuan, peserta didik, masyarakat, dan dalam mengembangkan silabus dilakukan melalui Musyawara Guru Mata Pelajaran yang kemudian disosialisasikan terutama kepada semua warga sekolah, pengawas, masyarakat dan pihak terkait. untuk sosialisasi tentang kurikulum 2013 untuk melatih kesiapan guru dalam melaksanakannya dilakukan pada saat musyawarah penyempurnaan kurikulum 2013 pada setiap awal pembelajaran, sedangkan untuk melatih kesiapan peserta didik dalam pelaksanaannya dilakukan pada awal tahun pembelajaran, sementara terhadap orang tua, sosialisasi untuk 
pemahaman tentang Kurikulum 2013 dilakukan pada saat rapat bersama dengan orang tua peserta didik pada awal tahun pembelajaran.

Pada aspek fasilitas pembelajaan, masih terdapat aspek-aspek yang perlu dilakukan peningkatan agar dapat mendukung penyelenggaraan program pembelajaran dengan baik, aspek-aspek tersebut, yaitu: aspek kondisi ruang pembelajaran menurut penilaian responden perlu diperbaiki terutama ketenangan dan kenyamanan ruang belajar, media pembelajaran belum sepenuhnya mencukupi serta tidak semua media pembelajaran dapat dipergunakan secara maksimal dan minimnya penggunaan media pembelajaran oleh guru mata pelajaran.

c. Iklim Kelas,

Dalam pelaksanaan proses Pembelajaran Pendidikan Agama Islam pada SMA di Kabupaten Maluku Tengah, berdasarkan hasil evaluasi menunjukkan bahwa segala situasi yang muncul akibat hubungan antara guru dan peserta didik atau hubungangan antar-peserta didik yang menjadi ciri khusus dari kelas mata pelajaran dan mempengaruhi proses pembelajaran dinilai termasuk pada kategori baik.

Terdapat beberapa aspek yang perlu ditingkatkan, agar aspek iklim kelas dapat menjadi lebih baik, sehingga penyelenggaraan program pembelajaran akan dapat berproses secara berkualitas yang pada akhirnya dapat menghasilkan output yang berkualitas pula. Berdasarkan hasil penilaian responden diketahui ternyata aspek-aspek yang perlu ditingkatkan, yaitu: pada aspek kekompakan peserta didik menurut penilaian responden perlu diperbaiki untuk lebih ditingkatkan, serta aspek keterlibatan peserta didik dan kepuasan peserta didik menurut reponden sebaikanya lebih ditingkatkan, karena itu peserta didik perlu diberikan kesempatan dan ruang yang cukup untuk berimpropisasi dalam program pembelajaran diantaranya dengan banyak melibatkan peserta didik dalam pelaksanaan proses pembelajaran.

d. Sikap Peserta didik,

Dalam mengikuti program pembelajaran Pendidikan Agama Islam pada SMA di Kabupaten Maluku Tengah, berdasarkan hasil evaluasi menunjukkan bahwa derajat afeksi positif atau negative peserta didik terhadap pembelajaran Pendidikan Agama Islam, khususnya materi Pendidikan Agama Islam yang dapat diukur melalui pengetahuan atau pemahaman, perasaan dan kecenderungan terhadap mata pelajaran, materi maupun guru dinilai dengan kategori baik. 
Sikap peserta didik terhadap pemahaman manfaat, kecenderungan dan rasa senang, seperti pada kegiatan ekstrakurikuler. Kegiatan ekstrakuriuler yang diselenggarakan secara keseluruhan cukup relevan dalam mendukung kegiatan pembelajaran, karena dalam menentukan kegiatan yang akan ditetapkan harus memiliki hubungan dengan peningkatan prestasi, sehingga pembinaan tidak rumit dan disesuikan dengan minat dan bakat, sementara prestasi peserta didik pada kegiatan ekstrakurikuler, cukup baik karena sering menjadi pemenang baik pada ivent antar sekolah maupun besama dengan SMA pada tingkat local maupun daerah, dan prestasi tersebut sangat berpengaruh pada prestasi pembelajaran sepanjang peserta didik tersebut selalu konsisten.

Aspek sikap peserta didik, meskipun pada kategori baik namun terdapat beberapa aspek yang perlu ditingkatkan, agar nantinya diharapakan sikap peserta didik menjadi lebih baik. Berdasarkan hasil jawaban responden diketahui bahwa aspek-aspek yang perlu ditingkatkan, diantaranya: aspek kecenderungan bertindak menurut responden perlu diperbaiki, karena itu perlu dilakukan melalui cara guru menganjurkan pada peserta didik untuk selalu perhatian dalam mengikuti program pembelajaran dan aspek orientasi keberhasilan dalam pembelajaran Pendidikan Agama Islam menurut responden perlu ditingkatkan, karena itu perlu dilakukan dengan cara menganjurkan pada peserta didik untuk mencari solusi jika mengalami kendala belajar dalam usaha mencapai prestasi.

e. Motivasi Belajar peserta didik

Dalam pelaksanaan program pembelajaran Pendidikan Agama Islam pada SMA di Kabupaten Maluku Tengah, berdasarkan hasil evaluasi menunjukkan bahwa dorongan dalam diri peserta didik untuk belajar, mengerjakan tugas-tugas memecahkan masalah maupun mempelajari kompetensi tertentu dalam mata pelajaran Pendidikan Agama Islam dengan sebaik-baiknya berdasarkan standar keunggulan, dinilai termasuk pada kategori baik.

Komponen kualitas proses pembelajaran menitikberatkan pada kinerja guru yakni interaksi antara guru dan peserta didik yang terjadi dalam konteks ruang kelas tertentu dengan dukungan fasilitas pembelajaran tertentu. Pola interaksi antara guru dengan peserta didik akan menumbuhkan iklim kelas tertentu, sehingga kualitas proses pembelajaran akan tergantung pada prilaku guru dalam mengajar di kelas, fasilitas pembelajaran dan iklim kelas. Kinerja guru yang baik akan mempunyai pengaruh terhadap iklim kelas, sikap dan motivasi belajar peserta didik serta hasil 
belajar peserta didik, iklim kelas yang baik akan mempunyai pengaruh terhadap sikap dan motivasi peserta didik serta hasil belajar peserta didik. Sikap positif peserta didik dalam kegiatan pembelajaran akan mempunyai pengaruh terhadap motivasi belajar peserta didik yang akan berpengaruh terhadap keberhasilan belajar Pendidikan Agama Islam peserta didik.

Motivasi belajar peserta didik meskipun pada kategori baik namun perlu peningkatan, terutama pada aspek tanggung jawab, dimana menurut penilaian reponden perlu ditingkatkan, karena itu perlu memberikan kepercayaan kepada peserta didik untuk mengerjakan dan menyelesaikan tugas-tugas yang diberikan dengan langkah-langkah yang efektif.

Secara keseluruhan realitas yang ditemukan pada penelitian evaluasi kualitas proses program pembelajaran Pendidikan Agama Islam pada SMA di Maluku Tengah berada pada kategori baik, namun terdapat beberapa aspek yang kurang atau tidak memenuhi standar sehingga menurut peneliti, disimpulkan perlu dilakukan upaya peningkatan dan perbaikan pada aspek tersebut.

\section{KESIMPULAN}

Melalui hasil temuan penelitian maka dapat ditarik beberapa kesimpulan tentang kualitas proses pembelajaran PAI pada SMA di Maluku Tengah, yang didasarkan pada kualitas proses pembelajaran di kelas. Proses pembelajaran ditentukan oleh unsur atau aspek berikut; (1) Kinerja Guru yang dinilai dengan kategori baik, dengan perolehan rerata skor 4,14 atau $82,79 \%$ dari skor maksimum, (2) Fasilitas Pembelajaran yang dinilai baik dengan perolehan rerata skor 3,71 atau $74,17 \%$ dari skor maksimum, (3) Iklim Kelas yang dinilai baik dengan perolehan rerata skor 3,61 atau $72,04 \%$ dari skor maksimum. (4) Sikap peserta didik yang dinilai baik dengan perolehan rerata skor 4,01 atau 80,09\% dari skor maksimum. (5) Motivasi Belajar Peserta didik yang dinilai baik dengan perolehan rerata skor 3,88 atau $77,71 \%$ dari skor maksimum. Sehingga berdasarkan hasil penialian dan kategorisasi pada aspekaspek tersebut di atas, dapat ditentukan bahwa kualitas proses pembelajaran PAI dinilai termasuk pada kategori yang baik, dengan perolehan rerata skor 3,88 atau $77,50 \%$ dari skor maksimum. Oleh karena itu, dapat ditarik kesimpulan bahwa komponen kualitas preses pembelajaran pada pelaksanaan program pembelajaran PAI yang dilaksanakan pada SMA di kabupaten Maluku Tengah dinilai termasuk pada kategori baik. 
Kelemahan pada proses pembelajaran, berdasarkan hasil evaluasi, antara lain (1) masih kurangnya penguasaan strategi pembelajaran, (2) gaya mengajar guru yang kurang variatif, (3) minimnya penggunaan media dalam pembelajaran, (4) peserta didik kurang dilibatkan dalam pelaksanaan proses pembelajaran, (5) guru kurang menganjurkan pada peserta didik untuk selalu perhatian dalam mengikuti program pembelajaran, (6) guru kurang menganjurkan pada peserta didik untuk mencari solusi jika mengalami kendala belajar dalam usaha mencapai prestasi, dan (7) guru kurang memberikan kepercayaan kepada peserta didik untuk mengerjakan dan menyelesaikan tugas-tugas yang diberikan dengan langkah-langkah yang efektif. Hal demikian berdampak pada kualitas proses pembelajaran PAI yang dilaksanakan pada SMA di kabupaten Maluku Tengah, walaupun rerata skor termasuk pada kategori baik, namun masih berada pada batas bawah, sehingga perlu diperbaiki pada beberapa aspek dari komponen kualitas proses pembelajaran tersebut, agar lebih akurat dan efektif.

\section{DAFTAR PUSTAKA}

[1] Aiken, Lewis R. (1996). Rating Scales and Checklist: Evaluation Behavior Personality, and Attitude New York: John Wiley \& Sons Inc.

[2] Arikunto, Suharsimi dan Cepi Safruddin Abdul Jabar, 2009. Evaluasi Program Pendidikan: Pedoman Teoritis Bagi Mahasiswa dan Praktisi Pendidikan Jakarta: Bumi Aksara.

[3] B. Sidharta, Raharjo. 2002. Pendidikan Berbasis Kompetensi Sebuah Kajian Kritis Yogyakarta: Universitas Atmajaya.

[4] Creswell, John W. 2014. Research Design, Qualitative, Quantitative and Mixed Methods Approaches Callifornia: Sage Publication

[5] Djamarah, Syaiful Bahri. 2002. Strategi Belajar Mengajar Jakarta: Rineka Cipta.

[6] Hamalik, Oemar. 2008. Perencanaan Pengajaran Berdasarkan Pendekatan Sistem, Jakarta:Bumi Aksara.

[7] Hidayati, Lili. Jurnal Insani, Kurikulum 2013 dan Arah Baru Pendidikan Agama Islam, Vol 19, No.12014.

[8] Jumaeda, St. Jurnal:Al-IItizam: Jurnal Pendidikan Agama Islam, Implementasi Standar Penilaian dalam Pembelajaran PAI pada Kurikulum 2013, Vol. 3, No. 1 2018

[9] Jumaeda, St. dan Nur Khozin, 2018. Implementasi Kurikulum 2013 dalam Pembelajaran PAI Ambon: LP2M. 
[10] Jumaeda, St. Dan Nursaid. Jurnal:Al-Iltizam: Jurnal Pendidikan Agama Islam Hubungan Sistem Pembelajaran Modul Terhadap Hasil Belajar Peserta Didik pada Mata Pelajaran Bahasa Arab di MTs DDI Seppange, Vol. 2 No.2, 2017

[11] Jumaeda, St. Jurnal:Al-Iltizam: Jurnal Pendidikan Agama Islam, Komparasi Bentuk Tes Pilihan Ganda Dengan Tes Menjodohkan ( Matching Test) Ditinjau dari Tingkat Kesukaran Pada Mata Pelajaran Bahasa Arab di MAN Waimital Kabupaten Seram Bagian Barat, Vol. 1, No. 1, 2016.

[12] Kemendiknas RI No 045/U/2002.

[13] Majid, Abdul. 2012. Belajar dan Pembelajaran Pendidikan Agama Islam Bandung: Remaja rosda Karya.

[14] Muljono, Djaali Puji. dan Ramly, 2004. Pengukuran Dalam Bidang Pendidikan Jakarta: PPs UNJ.

[15] Mulyasa, E. 2013. Pengembangan dan Implementasi Kurikulum 2013 Bandung: PT Remaja Rosda Karya.

[16] Nata, Abuddin. 2003. Manajemen Pendidikan Mengatasi Kelemahan Pendidikan Islam di IndonesiaJakarta: Prenada Media.

[17] Nuh,Mohammad.(2013). Kurikulum2013. http://kemdikbud.go.id/kemdikbud/artikel-mendikbud-kurikulum2013.diakses pada tanggal 9 Mei 2018

[18] Owen, John M. Program Evaluation: Froms and Approaches Sidney: Soutthwood Press, 1993.

[19] Putera Sampoerna Foundation (2012). 54 Persen Kualitas Guru Masih Rendah. (Online). Seputar Indonesia.com, diakses 21 Agustus 2018.

[20] Raharjo, Rahmat. Inovasi Kurikulum Pendidikan Agama Islam, Pengembangan Kurikulum Dan Pembelajaran Yogyakarta: Magnum, 2010.

[21] Rino, (2017) Kurikulum Perencanaan Implementasi Evaluasi, Inovasi dan Riset, Bandung: Alfabeta,.

[22] Roberts, Albert R. and Gilbert J. Greene, (2009). Buku Pintar Pekerja Sosial, terjemahan Juda Damanik dan Cynthia Pattiasina Jakarta: PT BPK Gunung Mulia.

[23] Spaulding, Dean T. (2008). Program Evaluatio in Practice: Core Consepts and Examples for Discussion and Analysis San Francisco: Joseey Wiley \& Sons, Inc.,

[24] Stufflebeam, Daniel L. dan Anthony J. Shinkfield, (2007) Evaluation Theory, Models, \& Applications San Francisco: Jossey-Bass.

[25] Sugiyono, (2009) Metode Penelitian Kuantitatif Kualitatif dan $R$ \& $D$ Bandung: Alfabeta.

[26] Sukardi, H. M. (2009) Evaluasi Pendidikan: Prinsip \& Operasionalnya Jakarta: Bumi Aksara.

[27] Tjahjono, Anang (2013). Petujuk Teknis Persiapan Implementasi Kurikulum Tahun 2013 pada Minggu Pertama di Sekolah. Direktorat Jendral Pendidikan Menengah Kementerian Pendidikan dan Kebudayaan,. 
[28] Widoyoko, S. Eko Putro.(2009). Evaluasi Program Pembelajaran: Panduan Praktis bagi Pendidik dan Calon Pendidik Yogyakarta: Pustaka Pelajar.

[29] Wiyani, Novan Ardy.( 2016) Inovasi Kurikulum dan Pembelajaran PAI SMA Berbasis Pendidikan Karakter Yogyakarta: Aruz Media. 